\title{
IAMJ
}

INTERNATIONAL

AYURVEDIC

MEDICAL JOURNAL

Case Report

ISSN: 23205091

Impact Factor: 5.344

\section{ROLE OF NASYA WITH KUMKUMADI TAILA IN IMPROVING DARK CIRCLES - A CASE STUDY}

\author{
Pranita Milind Deshpande', Anil Managuli²
}

${ }^{1}$ Final Year P.G. Panchakarma Scholar, ${ }^{2}$ Professor, Department of Panchakarma Shri. J. G. C. H, Society's Ayurvedic Medical College and Hospital, Ghataprabha, Belagavi, Karnataka, India

Email: anil.managuli@gmail.com

https://doi.org/10.46607/iamj3408082020

(Published online: August 2020)

Open Access

(C) International Ayurvedic Medical Journal, India 2020

Article Received: 07/07/2020 - Peer Reviewed: 01/08/2020 - Accepted for Publication: 01/08/2020

(D) Check for updates

\section{ABSTRACT}

Skin is a type of Gyanendriya (Sparshna indriya) and largest sense organ in the body. It is result of healthy constitution of body as well as healthy mental state. Skin has great cosmetological importance. Due to sedentary lifestyle, inappropriate diet habits and excessive stress, numerous skin aliments arise. Hence it is need for inculcating healthy skin care habits. One of the common worrying factors related to skin is Dark circles. It affects almost all age groups and is most commonly related to stress and anxiety. Drugs administered through nasal route acts on higher centers of the brain. It acts on neurological, endocrinal and circulatory centers and regulates their functions. This study is aimed to evaluate the role of Nasya Karma with kumkumadi taila in Dark circles.

Keywords: Dark circles Twacha, Nasya, Kumkumadi taila.

\section{INTRODUCTION}

Beauty is pleasant feeling that all individuals desire for. Beauty is not concern just with aesthetic or external value; it is internal quality that gives pleasure or satisfaction to our senses. Every individual's desire for healthy glowing skin. But due to current changing lifestyle, food habits and especially stress producing factors, it has become great concern to maintain healthy skin. One of such disorder dark circles. Though Dark circles are considered as minor aliment, yet it has major importance considering cosmetic value. According to Ayurveda, lakshanas of dark circles can be correlated with Vyanga lakshana like Niruja, Tanu, and Shava 
Varna Mandalas. Hetu of dark circles are: excess intake of Katu, Tikta, Kashaya, Amla, Lavana Rasatmaka Ahara, Abhishyandi Ahara Sewana, Usna, Tiksha Ahara Sewana, Vihara: stress and Diwaswapa, Ati krodha, Ati shoka, Ati bhaya (Manasika hetu)

Dark circles are caused by a variety of anatomic features, with contributions from the skin, subcutaneous tissues, orbicularis muscle, vasculature and ligamentous architecture of the lower eyelid and cheek. Possible reasons include excessive pigmentation, along with thin and luminous lower eyelid skin overlying the orbicularis oculi muscle. As people grow older, the skin gets thinner and collagen fibres are lost, at times augmenting the advent of tiny blood vessels beneath the eyes, thus making the area seems darker ${ }^{1}$. While lack of sleep and aging certainly play a role in under-eye discoloration, so do genetics, allergies, hormonal abnormalities, and accumulated skin damage ${ }^{2}$. Dark circles are most commonly seen in adult age and present generation spends a lot of money in glorifying skin by using various skin products which causes further skin damage.

Treating dark circles has become a problem since safe drugs are not available for long term effect. Modern treatments include topical creams that are marketed for the condition. Various ingredients have been researched, developed and included in these creams. For example, recently, chemical compounds called alpha hydroxy acids (AHAs) have been added as a beneficial ingredient to creams for dark circles. Specialist treatments including laser and intense pulsed light skin surgery can also be used ${ }^{3}$. Nasya is one of the Panchakarma which is indicated in Kshudra Rogas. Though dark circles appear locally yet there is systemic involvement also. Sthanik Chikitsa like Lepa, Abhyanga etc gives temporary relief but Nasya Chikitsa helps in pacifying Prakupita dosha and also promotes Twaka Prasadana.

Marsha Nasya with kumkumadi tailum has Varnya properties. Hence the main focus of article is bringing changes in colour of patches and also reducing size of dark circles.

Hence present study is aimed at evaluating the effect of Nasya Chikitsa in dark circles.

\section{Materials and Methods:}

Drug Source: Kumkumadi Tailum ${ }^{4}$ by Nagarjuna pharmacy was procured from market for Nasya Upkrama Dropper, cotton, gas burner, utensils required for making oil Sukoshna.

Case Report: A 27 years old married female of $\mathrm{Va}$ takapha Prakruti suffering from $\mathrm{C} / \mathrm{O}$ dark circles since 5 months visited OPD. There was no sign of inflammatory pigmentation or Ruja present. She had irregular bowel habit and Mandagni. When detailed history was taken it was noticed that patient was working in IT sector, having stressful situations and sedentary lifestyle. Regarding food habits it was observed that patient used to skip meals or used to take meals in large quantity at once. Meals constituted mainly of Guru, Snigdha, Abhishyanda Ahara especially bakery products. There was no appropriate sleep pattern observed, patient used to work for late hours and H/O Diwaswaapa was noted. Along with that Mansasik Hetu such Atibhaya was noticed. When intrigued about the same, it revealed that due to working timelines, at times Atibhaya lakshanas were noticed. On examination size of dark circles, its colour shade was noted down based on fairness scale meter. There was H/O patient taking allopathy treatment for same for past 2 months, but no significant result was observed.

Treatment protocol: After assessment and examination, patient was subjected to Kumkumadi Taila Nasya for 7 days. Assessment was done based on subjective and objective parameters before and after treatment. A scoring pattern was prepared for subjective and objective parameters. On the day of Nasya Karma, written informed consent was taken. Patient was given Tablet Shankha vati for 3 days for the purpose of Deepana and Pachana. Then Nasya Karma was done assessing Roga Bala, Rogi bala and Yogya Ayogyata of Nasya Karma. In this patient Matra adopted was 10 Bindu which is Uttama matra of Marsha Nasya. As discussed earlier, Nasya Karma was done for 7 days. After 7 days followup was taken, and grading pattern was observed. Same procedure was repeated.

\section{Administration of Therapy}

Abhyanga: was done on the Mukh Pradesha for about 5 mins with Manjistadi Taila. It was done continuously 
for 7 days in the morning. After performing the $A b$ hyanga, Mrudu Swedana was done each day with the vapour of boil water and covering the patients with blanket. After Abhyanga and Swedana, 10-15 rest was given. Marshyanasya: Was given with Kumkumadi Tailam, 10 drops in each nostril. It was done continues for 7 days in the morning in between 7-8 am with the classical procedure. During the procedure, Samyaka Nasya Shuddhi Lakshana or presence of any other Lakshana's were observed and recorded.

Paschat karma: Dhumpana Kawalagraha and Gandusha was advised, Dhumpana = Hardiravarti (3 times). Pathya: Patients was advised to take Laghu Ahara, Na Ati Snigdha Ahara, Anaabhishyangi Ahara and Ushna Ahara. Apathya: Avoid cold drink, bakery products, heavy food

\section{Follow up:}

15 days of follow up was advised to the patients. Study Duration: 21 days

\section{Contents of Kumkumadi tailam}

Kumkuma, Usheera, Kaaleeya, Laksha, Yashtimadhu, Chandan, Nyagrodha, Padmaka, Neelotpala, Manjishta, Patranga

Inclusion Criteria: Age group 20-30 years. Chronicity less than 5 years, Patients fit for Nasya Karma., Having lakshanas like Niruja, Tanu and Shava Varna Mandalas.

Exclusion Criteria: Inflammatory pigmentation, Malignant melanoma, Acne vulgaris, Pregnant women and lactating women, Other skin diseases like Addison's disease, SLE, drug induced photo sensitivity were excluded.

Assessment Criteria:

Subjective Criteria: circumcised dark circle patches underneath eyes. Neerujam, Vaivarnya (brownish to blackish)

Objective Criteria: The colour of dark circle before and after treatment were noted on the basis of the fairness meter

Table 1: Scoring pattern

\begin{tabular}{|l|l|}
\hline Lakshana & Score \\
\hline Mild & $1-8$ \\
\hline Moderate & $9-16$ \\
\hline Severe & $17-26$ \\
\hline
\end{tabular}

Table 2: Size of dark circles

\begin{tabular}{|l|l|}
\hline Lakshana & Size \\
\hline G1 & Total disappearance of dark circles \\
\hline G2 & $1 / 2-2$ sq.cm \\
\hline G3 & $3-5$ sq.cm \\
\hline G4 & Greater than 5 sq.cm \\
\hline
\end{tabular}

Table 3: Grading for Clinical improvement of variable

\begin{tabular}{l|l} 
Grading scale & Indicates \\
\hline Good & Significant Reduction in colour and Size of dark circles \\
\hline Moderate & Reduction in colour of dark circles without reduction in size of dark circles \\
\hline Poor & No reduction in colour and size of dark circles
\end{tabular}

Table 4: Criteria for Assessment

\begin{tabular}{|l|l|l|l|l|}
\hline Lakshana & $1^{\text {st }}$ day & Day 7 & Day 14 & Day 21 \\
\hline Change in colour as per fairness meter. & 22 & 18 & 13 & 8 \\
\hline Size of Dark circle Unit per $\mathrm{cm}^{2}$ & 5 & 4 & 3 & 2.5 \\
\hline
\end{tabular}




\section{DISCUSSION}

While discussing about dark circles special importance is always given to psychological factors like Krodha, Shoka, Shrama which are commonly found in most of patients. Considering the above causes, it can be postulated that there is Vata Pitta and Rakta Prakopa. Hence, we can conclude that very first Dhatu which gets affected is Rakta Dhatu, it vitiates Agni (Pitta Dosha) which resides in Rasa Dhatu and initiates pathogenesis of dark circle. Here Ranjaka Pitta is responsible for conversion of Rasa Dhatu into Rakta Dhatu which helps in generating normal skin tone. However due to above said Hetus, it affects Jataragni and hampers normal functions of Ranjaka Pitta Based on Ashraya-Ashrayee Bhavas, the derangement of Pitta Dosha leads to abnormality of Rakta Dhatu. Shrama and Shoka will lead to Udana Vata vitiation. Thus, vitiated Ranjaka Pitta, Rakta Dhatu as well as Udana Vata travel in body through Dhamanis and get Sthana Samshraya in Mukhagata Twacha and causes vitiation of Bhrajaka Pitta giving rise to discoloration of the skin. Nasya is said to be Nasa hi Shirsodvarum states that it is closest opening for conveying potency of medicines to cranial cavity. The Nasya Dravya acts by reaching Shrungataka Marma from where it spreads to all sukshma strotasa and pacifies Dosha Prakopa.

\section{Possible Mode of Action of Kumkumadi Taila:}

Kumkumadi Taila administered in form of Nasya reaches to Shrungataka area, spreads in Murdha and helps to remove the Prakupita Dosha and also balances the function of endocrinal system and maintains hormonal balance. Also, it gets absorbed by nasal mucosa and enters in circulatory system and pacifies Prakupita Rakta and Rasa Dhatu. Contents of Kumkumadi Taila include Kumkuma, Haridra, Darvi, Pippali as Kalka Dravya and Chitraka as Kwatha Dravya along with Taila. All ingredients are basically Katu, Tikta Rasatmaka and Usna Viryamatka having Vata- Kaphahara properties and Varnya properties. (Sharma, P.V (2011), Dravya Guna Vidyana, Chaukhambha publications, Varanasi) hence causes Twaka Prasadana and helps in restoring natural skin tone.

Result: After the 21 days of the treatment significant colour changed was noticed in the dark circle. The gradations of change in colour and size of dark circles are mentioned in below graph. On the first day of Nasya Treatment the change in colour was noted as 22 as per Fairness meter and size was $5 \mathrm{~cm}^{2}$. On the $7^{\text {th }}$ day of Nasya Treatment the change in colour was noted as 14 as per Fairness meter and size was $4 \mathrm{~cm}^{2}$. On the $14^{\text {th }}$ day of Nasya Treatment the change in colour was noted as 10 as per Fairness meter and size was $3 \mathrm{~cm}^{2}$. On the $21^{\text {st }}$ day of Nasya Treatment the change in colour was noted as 8 as per Fairness meter and size was $2.5 \mathrm{~cm}^{2}$.

\begin{tabular}{|l|l|l|l|l|}
\hline Lakshana & $1^{\text {st }}$ day & 7 th Day & 14 th Day & 21 st Day \\
\hline Change in colour as per fairness meter. & 22 & 18 & 13 & 8 \\
\hline
\end{tabular}

\begin{tabular}{|l|l|l|l|l|}
\hline Dark Circle Size & $1^{\text {st }}$ day & 7 th Day & 14 th Day & 21 st Day \\
\hline Unit per $\mathrm{cm}^{2}$ & 5 & 4 & 3 & 2.5 \\
\hline
\end{tabular}

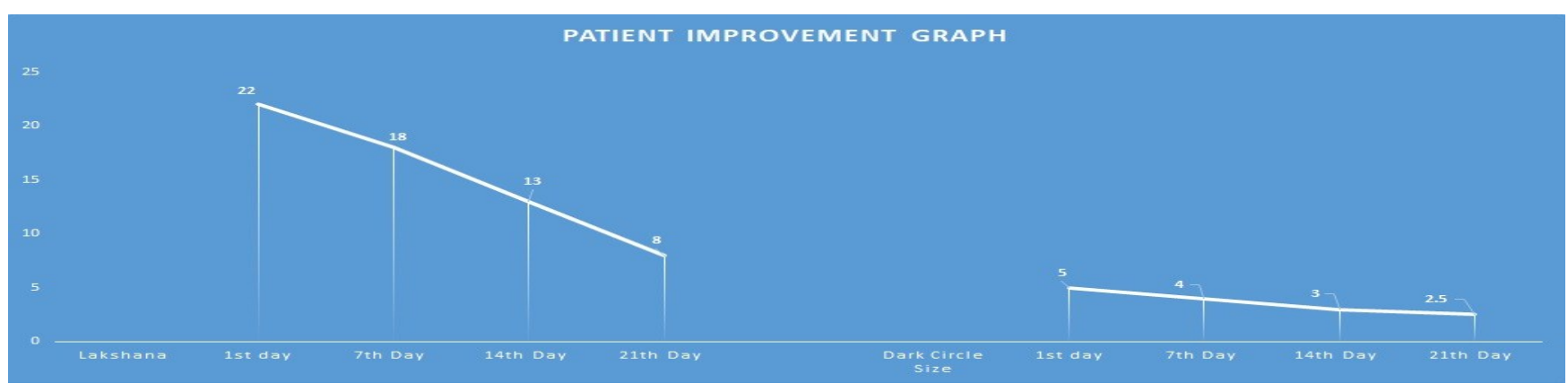

Figure 1 Patient Graph 


\section{CONCLUSION}

As Kumkumadi Taila is Vata-kaphahara it pacifies the Dosha Prakopa and causes Twaka Prasadna

As the case showed mark relief in the colour change and the reduction in the size it can be concluded that this treatment modality can be prescribed that standard procedure considering its efficacy and safe regiment dark circle. A Large scale clinical must be conducted to establish the efficacy of the modality of the treatment with longer follow up.

\section{REFERENCES}

1. Freitag FM, Cestari TF. What causes dark circles under the eyes? J Cosmet Dermatol 2007; 6(3): 211-215. doi: 10.1111/j.1473-2165.2007.00324. x.

2. Verschoore M, Gupta S, Sharma VK, Ortonne JP. (Determination of melanin and haemoglobin in the skin of diopathic cutaneous hyperchromia of the orbital region (ICHOR): A study of Indian patients. J Cutan Aesthet Surg 2012; 5(3): 176-182. doi: 10.4103/09742077.101371.)

3. www. Wikipedia.org. Alpha Hydroxy acids retrieved 2016/06/29 and under eye circles retrieved 2016/06/29)

4. Vaidya Yadavji Trikamji Acharya Edited Ashtanga Hridayum Sutrasthana (32/27-30), Chaukhambha Surabharati Prakashan, reprint 2008)

\section{Source of Support: Nil}

\section{Conflict of Interest: None Declared}

How to cite this URL: Pranita Milind Deshpande \& Anil Managuli: Role Of Nasya With Kumkumadi Taila In Improving Dark Circles - A Case Study. International Ayurvedic Medical Journal \{online\} 2020 \{cited August, 2020\} Available from: http://www.iamj.in/posts/images/upload/4245 4249.pdf 